\title{
Civil or Un-Civil Society? Islamist Identity, Democracy and Civil Society in Contemporary Surakarta
}

\author{
Abzar, D \\ IAIN Samarinda, Samarinda, Indonesia \\ abzar stain@yahoo.com \\ Muzayyin Ahyar \\ IAIN Samarinda, Indonesia \\ muz.ahyar@gmail.com
}

\begin{abstract}
This article attempts to analyze the development of an ideology of Islamism that rejects the political system of democracy through the reasoning of civil society. As a study of civil society and democracy, this article has significance in understanding the complexities of democratic practice in the scope of the identity of Islamist groups post-democratization in Indonesia. The proliferation of Islamist movements in grassroots communities in Indonesia is a unique phenomenon that has a dualistic meaning. On the one hand, Islamist opposition to the democratic system can be a threat to the continuance of evolving democratic theory. On the other hand, the actions they do have a good tendency in running the logic of democracy by realizing positive law as the reference in conveying their aspirations. This article was held on several examples of cases of Islamist groups in Surakarta namely Laskar Umat Islam Surakarta. Based on intensive field studies and in-depth interviews with the movement figures, this study reveals that the existence of Islamists in Surakarta is still in line with the big narrative of civil society ideas, i.e., good society, social life and free public sphere. In case of expressing aspiration, Islamism activists try to make a mass rallies, lobbying with stakeholders, involving the security apparatus, political bargaining, and setting up legal communities, which these all are some reasonable endeavors as part of civil society in a democratic country. Therefore, remind them of the idea of democracy as well as follow the democratic practice that can be a trigger for legal awareness for a democratic society in Indonesia.
\end{abstract}

Keywords-civil society; Islamist movement in Surakarta; democracy.

\section{IN T R O D U C T IO N}

The fall down of the New Orders' authoritarian regime brought a broad impact on national political nuance. The wave of democratization has been too strong to be dammed, which gives birth to groups with multiple identities [1]. The democratization that Huntington says signifies the emergence of a free public sphere, social movements that increasingly emerge to show its existence, democratic electoral system, and a guarantee to the freedom of assembly, association and forming organizations. One of Islamist social movement that proliferates in the aftermath of Reformasi is Laskar Umat Islam Surakarta (LUIS). This Islamist movement takes a role in as an Islamic social movement and places itself as the frontline defender of the ideology of Islamism.

The emergence of various Islamist movements in Surakarta is currently the proliferation of the long history of the Islamic movement in Surakarta since the era of Dutch occupation in Indonesia [2]. The presence of Islamism movement as opposed to democracy is considered to be a serious scourge for the continuity of plural society in Indonesia. Various violence actions that occurred in Solo at the beginning of the post-democratization decade in Indonesia seem to confirm the truth of democracy threat.

In the last decade, Islamist movements in Surakarta have undertaken actions of emphasis on state institutions; they are actively involved in the policing effort, even in the "radical" action. There is an ambiguity about the Islamist activists in this era of democracy; on the one hand, they reject democracy that claimed un-Islamic concept. But on the other hand, they have to follow the logic of democracy which is just a reason to make it survive in the middle of freedom of expression in the democratic era. Itcertainly enriches new discourse and discussion for the study of Islam, democracy and civil society.

The proliferation of Islamist group in Surakarta raises some questions; are these movements kind of un-civil society? How the Islamist groups pursue the labeling of democrat Muslim civil society in the middle of ongoing democratization in Indonesia? This article emphasizes the analysis on how Islamism ideology pursues the public acknowledgment as a democratic religious mass organization and how this discourse adapted in the context of civil society and democratic circumstance.

\section{CIVIL SOCIETY IN LITERATURE}

The conceptual development of civil society has been theorized by the earlier scholars. Indeed, civil society is the most confusing concepts in social science. The abundance of 
banal definitions makes this term too difficult to be redefined consistently. Civil society began to be studied by several scholars in the post-democratization of European countries. Nevertheless, the embryo of thought was born long before that. If civil society means as an independent society that supports the performance of government, then the study of civil society can be traced back from various articles of classical Greek philosophers relating to public relations in developing countries [3], [4].

In the modern era, civil society is considered as every single activities or association (families, communities, and countries) that benefit the state agenda. In the post-modern era, the discourse of civil society again strengthened as the effect of the clash ideologies between liberalism-democracy and communism. Several perspectives on society and state began to be varied. The different identities in forming an independent community begin to resonate in the community. The peaceful political and social circumstance of various independent groups in a free public sphere is known as civil society. In this context, civil society organizations cover a wide range of entities of different types, sizes, purposes and levels of a community including social movements and grassroots associations [5]

The debate on civil society came to be discussed again when the emergence of some exclusive groups that emerged from the world ideological warfare in the World War 2. In 1989, Communist had to bolster the Eastern European countries to have negotiating partner. This overlooked establishment from the opposition of anti-communism countries called by "uncivil society," in another way, un-civil society is the political circumstance that has opposite to liberal democracy ideology [6].

Marco Garrido tries to discuss the differences between civil and uncivil society according to the two cases of mass demonstration around the Epifanio de Los Santos Avenue (popularly called by EDSA, a hallowed site in the city's geography of protest). Through the case of EDSA 2 and EDSA 3, Garrido found a symbolic distinction between civil and uncivil society. EDSA Revolution or also known as People Power Revolution, it was a series of popular demonstration in the Philippines which has begun in 1986. The second EDSA (EDSA II) occurred in January 2001, the four-day political protest that peacefully for overthrowing the regime of Joseph Estrada, the thirteenth President of Philippines. The EDSA III was the continuance of the EDSA II protest in April - May 2001. According to Garrido, there are some differences regarding performances of opposing conceptions of citizenship. The significant difference between civil and uncivil society is that civil society categorized by organized action, morally legitimate and legal citizen movement. Uncivil society is defined as disorganized, sporadic action or, morally illegitimate, illegal citizen movement, and resulting from elite manipulation. EDSA II is manifested as one conception based on normative ideals like good governance, the rule of law, bureaucracy and nationalism. On the contrary with EDSA II, EDSA III enacted a counterclaim for citizenship by positing a conception based on the demand for recognition and equal consideration, as well as entitlement norms. This counterclaim explicitly rebutted the conceit of EDSA II forces that represented the people. By promulgating a definition of citizenship shorn of cultural criteria, the demonstrators appropriated the narrative of popular sovereignty, compelling EDSA II forces to shift the emphasis of their argument to questions of civic competence by a different narrative, that of "progress" [7].

If an exclusive group opposed to the ideas of liberal democracy is called an "uncivil society," Islamism as an ideology of political Islam are also included in the Uncivil category. But, is it not too early to call Islamists as an "uncivil" group?

\section{SURAKARTA AND ISLAMIST IDENTITY}

Solo has a long socio-political dynamics in facing the trajectory of Islamist movements along the history of Indonesia. The journey of the Islamist movement has always been transformed into a new movement, also with new characteristics and strategies, in every political period passed by the Republic of Indonesia. Dissimilar to other areas, Solo is well known for its local Islamist vigilante group that proliferates into a varied movement. With this reason, we chose Solo as our research locus to gain the validity of social research

The presence of Laskar Umat Islam Surakarta (LUIS, Muslim Vigilante Group of Surakarta) as the proliferation of Islamist movements in Surakarta is not a new phenomenon. The history can be traced back to every single of the political regime in Indonesia. Surakarta had earlier generated for the first Islamic movement against the Dutch colonial government known as Sarekat Dagang Islam (SDI) and later transformed into Sarekat Islam (SI). In the Soeharto Era, the two main actors of Islamism Abdullah Sungkar and Abu Bakar Ba'asyir came in the list of successors of the Islamist movement in Surakarta.

After the Reformation, Surakarta remained a region famous for the proliferation of some Islamist movements to establish the Islamism identity by struggling through Islamic political activism. Since the transition period, some local Islamic vigilante group in Surakarta have formed ideology to realize Islam as a struggle movement. They are Laskar Jundullah (Soldier God Islamic vigilante group) which is part 
of Forum Komunikasi Aktifis Masjid (FKAM, Mosque Activist Communication Forum), Laskar Hizbullah (Party of God Islamic vigilante group), Front Pemuda Islam Surakarta (Islamic Youth Front of Surakarta) and Laskar Umat Islam Surakarta (LUIS, Muslim Vigilante group of Surakarta).

Several these local Islamist movements find their momentum to consolidate the power of movements when the social riot in Ambon and Poso (1998-2001). The uncertain socio-political atmosphere during the social conflict makes some actors from several Islamic groups consolidate to found the convergent mass organization of these Islamic groups. They got gather at the Sriyadi's House, in Pajang, Solo Central Java. The gathering agreed on the establishment of new Islamic mass organization as a massive effort in consolidating Muslim power in Solo and responding the bloody social riot in Ambon and Poso. In this moment, Laskar Umat Islam Surakarta has found as a convergent organization by the 10 people of initiator; Edi Lukito, Salman al-Farisi, Hendro Sudarsono (Laskar Mujahidin), Jayendra Dewa, Yusuf Suparna, Muhammad Kalono (FKAM/Laskar Jundullah), Yani Rahmanto (Hizbullah), Khairul (FPIS, Islamic Youth Front of Surakarta), Heru Prayetno (Majelis Tafsir al-Qur'an) dan Sriyadi (Komando Kesiapsiagaan Angkatan Muda Muhammadiyah, Muhammadiyah's Security command). The establishment of Laskar Umat Islam Surakarta declared in Kota Barat Stadium, Solo and led by Edi Lukito who currently the chief of the organization [8].

\section{HOW ISLAMISTS ACT?}

The establishment of Laskar Umat Islam Surakarta as a unifying mass organization of Islamist ideology in Solo currently plays a role in spreading of Islamism discourse and non-litigation advocacy, for example: enforcement of sharia (sharia by law), resistance to stigmatization of terrorism to Islam, anti-American and global capitalism, religion blasphemy, empowerment of Muslims, law enforcement and justice. Laskar Umat Islam Surakarta makes government and civil society an idea of propaganda of its Islamicism museum. In addition to sweeping people who violate religious and positive law provisions, they also expressed their protesting aspirations to various state institutions such as regional government of Solo city and Dewan perwakilan Rakyat Daerah Kota Solo (DPRD, Regional People's Representative Council). Their aspirations vary greatly; implementation of sharia law, fair law enforcement, dissolution of Special Detachment (Densus) 88 Anti-Terror, which is considered as an unprofessional team because the brutality against a civilian who become suspect in terrorism.
Keeping commitment to a democratic country, Indonesia government has a dilemma in facing the proliferation of Islamist movement. In the one hand, the state cannot hamper the freedom to associate and assembly because of the demanding of democracy. But on the other hand, the state has to strive to encounter the continuous violent action since the last year's post-democratization era.

Some of these Islamist movements are still occasionally involved in self-raid actions against some places. The Islamism movement then considered by some reporting analysis as an extremist group which seriously spreading terror to the civilian. It is this democratic nuance that gives Islamists the advantage to remain free to voice their identity. However, the pace of democratization in Indonesia is also linked to the rapid development of information technology that makes easy news in various media Reports from international anti-terror agencies such as the International Crisis Group gave birth to the perception that the Islamists are extremists who always spread terror [9].

With the frequent news coverage in various mass media that Solo is a terrorist city, some young activist of Islamism in Solo take the initiative to change the flow of movement strategy in a more closer to democratic spirit than the sporadic radical action. Various communities are formed and renewed in line with the vision of Reformasi Indonesia that opens the nuances of democracy in Indonesia. Laskar Umat Islam Surakarta then registered for the issuance notarial act to legalize the organization. Nowadays, they try to digitalize their action by playing a role in cyber activism. The activist of Laskar Umat Islam Surakarta have been consolidating their power and promoting the Islamism ideology through the social media and online instant messenger like Facebook, Instagram, WhatsApp, Line, and BlackBerry messenger since the beginning of internet mushrooming in the middle-class society in 2013. Through the internet, they can freely show their attention in religious and state problems at once like religious blasphemy, non-Muslim leader, corruption, injustice, social gap and law enforcement.

Indeed, ideologically, the members of LUIS have often voiced their rejection of democratic ideas by spreading the propaganda that there are many disorders of the democratic system and promoting the divine political system. The supporters of the democratic system will judges as a sinner. The exclusive attitudes to diversity also become a contrast to the values of democracy and the ideals of civil society. However, some transparent attitudes, following legal procedures and realizing the freedom to assembly, to associate and to present the opinion are things which show an attitude that is close to the core values of democracy. Due to the attitude ambiguity, it is very difficult to determine whether 
LUIS belongs to civil or uncivil society. However, I argue that voicing democratic values is the best strategy in fighting for freedom of association. Using the values of democracy, they try to map out the potential societies could be urged for struggling an Islamic political ideology. This is the problems faced by democratic countries when dealing with Islamists who use democracy as a strategy precisely to destroy democracy itself. Democracy can be trapped by undemocratic attitude because of democracy should accommodate various political ideology; even some ideologies oppose the democratic values [10].

\section{CIVILITY IN ISLAMIST MOVEMENT: LASKAR UMAT ISLAM SURAKARTA}

Because of the democratization process, Laskar Umat Islam Surakarta safely actualizes the idea and identity of Islamism. They have to adapt the strategy of propaganda by the democratic values;

\section{A. Establishing The Legal Social Movement}

The establishment of LUIS in the democratic realm becomes a movement with the aim of having control over government institutions, social changes, and competing in the free public sphere. Several movements in the era of democracy lead to the control over the social change that is considered as one causes of deterioration, At once as a promoting identity [11]. By having competition consciousness in the free public sphere, they try to build a civil society with the spirit of independence in organizing the social movement.

\section{B. Networking and Mass Rallying}

The activists try to survive in the flow of democracy by exploiting the vast network in Solo area and its surroundings. Their network is built from mosques in densely populated areas, where the mosque is rarely noticed by residents so there is minimal religious activity other than congregational prayers. The vacuum of mosque activity in Solo became a challenge for LUIS to better color the mosque with activities that blow ideological spirit; they initiated the ideological activity by conducting routine studies at the mosque. The teachings held are open to the public, but the ustadz who fill the routine studies have been determined following the ideology that is believed. Laskar Umat Islam Surakarta makes beberaoa mosque as a place to build social networking. Some of them are big mosques and the smaller ones (mushalla) located in the corner of the alley or the settlement of the residents.

The activists have no significant difficulties in collecting networks and mobilizing the masses to act in the nowadays era of globalization and modernization. Technology can create boundaries between groups and simultaneously unify other boundaries. By using a smartphone, the activists create the online networks. They gather, share information, and learn the Islamic political notion digitally. The process of mobilization is so easy to accelerate their movement in action. They gathered quickly in a predetermined place to launch other political actions such as mass demonstrations for forcing the rejection of draft local regulations on liquor (2014), closing unlawful nightclubs, and protesting the performance of Densus 88 Anti Police Terror that they deem as unprofessional unit of Police and often violate the standard operation procedure (2010 - present).

\section{Actualization Of Critic To The Democratic Institution}

On Mei 2017, ten members of LUIS were acquitted by Pengadilan Negeri (the general civil judicature) Semarang. Previously, the ten defendants were arrested for allegedly violating sweeping conducted at Solo's Social Kitchen Restaurant, Central Java. During the trial, LUIS had its team in defending one of the rights of citizens. Previously, the ten defendants were arrested for allegedly violating raid at Social Kitchen Restaurant, Solo Central Java. During the court session, LUIS had its team in defending one of the rights of citizens.

Several people within the circle of the Solo Islamist movement formed a working team to defend members of the group that were involved in a legal case. This small team is called the Tim Advokasi Umat (TAU, Advocacy Team of the Umat) (TAU). The consolidated team was formed in 2015 which also defends other Islamists when it comes to legal cases. The Advocacy Team of the Ummah consists of 12 scholars who have been certified as advocates and chaired by Muhammad Kalono, a famous actor in the Islamist movement in Solo.

Members of LUIS always claim that their actions do not immediately take to the streets of sweeping or other radical actions. The action is always through various stages: starting with the monitoring, warning and reporting stages. If the reporting has no serious respond from the officer, then they do the protest by raiding directly to the target object.

By carrying out these radical actions, the members of LUIS take advantage of the weaknesses that still occur in democratic countries, especially in the issue of law enforcement. The LUIS activists are not blind to positive law in Indonesia. Some of them are law graduates who understand the legal issues. They are trying to target the weaknesses in the enforcement of these laws as an affirmation of identity in a society that they are entitled to be supported for the discourses of Islamism voiced, which is claimed to improve all the problems in Indonesia. The radical actions are the critical space expressed by LUIS in the flow of democracy to remain a 
citizen contributing to the progress of law enforcement. Although it has violated the procedure, it is possible to if the radical forces, aspirations, and actions of the Islamist groups are considered as the strengths of other Islamic civil society as a warning of the weakness of law enforcement in Indonesia.

These three actions could be categorized as a civil society according to Garrido's argument that LUIS is one movement that closes to some characteristic features; organized action, morally legitimate and legal citizen movement.

\section{CONCLUSION}

The establishment of Laskar Umat Islam Surakarta movement can be realized because of the democratic growth and globalization process that opens the barriers to widespread public participation. They, therefore, actualize themselves in ways and devices adapted to the democratic circumstances, such as establishing social movements as the actualization of civil liberties, mass networking, involving some Islamist actors in decision making, and criticizing of government institutions as a process of checks and balances. In this context, LUIS is present as an effort to seize the public sphere by exploiting the ever-changing political opportunities. However, in many respects, Islamist groups at the same time put the threats that deny the principles of democracy such as human rights, pluralism, and multiculturalism that grow along with the process of democratic growth. In the spirit of jihad, some tendentious actions to curb the "other" rights of different religions become a kind of concrete evidence of the threat. Nevertheless, the establishment Laskar Umat Islam Surakarta signifies the contestation of identities in the free public sphere. In case of expressing aspiration, Islamism activists try to make a mass rallies, lobbying with stakeholders, involving the security apparatus, political bargaining, and setting up legal communities, which these all are some reasonable endeavors as part of civil society in a democratic country. Therefore, remind them of the idea of democracy as well as follow the democratic practice that can be a trigger for legal awareness for a democratic society in Indonesia. 


\section{REFERENCES}

1. Huntington, Samuel P. 2012. The Third Wave: Democratization in the Late 20th Century. University of Oklahoma Press

2. Wildan, Muhammad. 2008. Mapping Radical Islamism in Solo: A Study of Proliferation of Radical Islamism in Central Java, Indonesia. AlJami'ah: Journal of Islamic Studies

3. Plato. 2013. Republic. Harvard University Press

4. Aristotle. 2010. The Politics. University of Chicago Press.

5. Edwards, Michael. 2011. The Oxford Handbook of Civil Society. USA: Oxford University Press

6. Kotkin, Stephen. 2009. Uncivil Society: 1989 and the Implosion of the Communist Establishment. Random House Publishing Group.
7. Garrido, Marco. 2008. Civil and Uncivil Society Symbolic Boundaries and Civic Exclusion in Metro Manila. Philippine Studies

8. Ahyar, Muzayyin. 2015. Gerakan Islam Radikal Dan Pertumbuhan Demokrasi Di Indonesia (Studi Atas Kelompok Islamis Lokal Tim Hisbah Solo). UIN SUNAN KALIJAGA. http://digilib.uin-suka.ac.id/17397/.

9. How Indonesian Extremists Regroup. 2012. https://www.crisisgroup.org/asia/south-eastasia/indonesia/how-indonesian-extremistsregroup.

10. Fuller, Graham, and Francis Fukuyama. 1992. The Democracy Trap. New York, N.Y., U.S.A: Dutton Adult.

11. Esposito, John L., and John Obert Voll. 1996. Islam and Democracy. Oxford University Pres. 